\title{
The Right of Reply in a European Comparative Perspective
}

\begin{abstract}
The purpose of the present paper is to identify the legal position and role of the right of reply within the European concept of media law. We wish to find an answer to the question whether the right of reply constitutes a limitation to the freedom of the press or if it is to be understood as a means of exercising freedom of opinion (or both, perhaps). We shall also try to identify the common foundations of the regulation of the right of reply and its general, or at least, most common, manifestations in Europe. According to our preliminary hypothesis, the right of reply is a legal instrument serving both the person whose (personality) rights have been violated (the applicant in the legal procedure) and the public wishing to access a wide variety of information via the media. The conclusions of the paper shall confirm or refute this hypothesis.
\end{abstract}

Keywords: right of reply, right of rectification, defamation law, libel law, comparative media law

\section{Issues of terminology, clarification of concepts}

In a certain sense, the expression "right of reply" is misleading. There are several different rights entitling the victims of libel and defamation to assert their rights against the media and obliging the latter to publish a reply. These may be called right of reply or right of rectification. The difference is between the scope of the rights and the possible extent of the content of the reply statement. The right of rectification or correction usually provides for a brief correction of false or inaccurate statements, i.e. it does not enable the publication of any content other than this; the statement calls, in official and bland terms, the attention of the public to the falsehood of the published facts and indicates what the actual state of affairs is. In comparison, the right of reply allows the injured party to present their position in a comprehensive manner in respect of the disputed issue; i.e. it is not limited to the rectification of false information. The right of reply becomes even broader if it is applicable against injurious statements of opinion. At the same time, these two "basic models" are strongly simplified, since there are no two wholly identical regulatory frameworks in Europe, and several states apply a combination of the two models (either by differentiating between the regulation of press products and media services or by admitting several different forms of reply). That is, the best we can do is to use the term "right of reply" as a collective concept encompassing all legal solutions that serve a similar purpose. (Hereinafter we shall use the term in this sense.)

Furthermore, we should also mention the rule of retraction, which exists in several states of the United States and is somewhat akin to the right of reply. On the basis of the provisions governing retraction, a person about whom false and injurious statements have been published in the media may demand the correction of these. If this is appropriately performed, the injured party's right to sue for libel is usually waived or the amount of damages claimable is decreased significantly (e.g. it is limited to "actual damages" or "special damages", as in the case of the legislation of California and Iowa). In most states

* Associate professor, Pázmány Péter Catholic University Faculty of Law and Political Sciences, H-1088 Budapest, Szentkirályi u. 28-30.

E-mail: koltay.andras@jak.ppke.hu 
where retraction exists, the submission of the application for correction and its rejection or inappropriate performance by the media is a precondition to the subsequent initiation of court action. ${ }^{1}$ That is, retraction is closely related to the right of reply, but with the not negligible difference that the former does not generate, in any way, a direct possibility for the injured parties to "have their say" in the media.

\section{International context}

\section{The European Union}

In respect of television service providers domiciled in the European Union, the community directive $^{2}$ has prescribed since 1989 that the legal system of the member states must provide the right of reply to the victims of defamatory statements. This does not necessarily mean that it is mandatory for all member states to provide for the right of reply: according to the text of the directive, a "legal remedy equivalent" to the right of reply is sufficient as well. Since, in the majority of the member states, some sort of right of reply has been in existence for a long time, while others apply instruments serving similar purposes (even in the field of co- and self-regulation), the adoption of this provision of the Directive has not caused any problems.

It is important to stress that the Directive only demands that member states ensure the right of reply against false statements; the violation of good reputation and honour by statements of opinion does not fall under its scope. However, as the Directive only contains the necessary minimum provisions, the member states may apply within their own legal systems stricter provisions and may extend the right of reply over injurious statements of opinion, too (actually most member states did extend the scope of the right).

Paragraph (3) of the Directive covers procedural issues while paragraph (4) concerns cases when reply may be refused in rather general terms. Paragraph (5) is important because it prescribes that, with regard to disputes concerning the right of reply, legal remedy by a court of law must be provided (if in a member state the decision of a court of law is required in respect of the exercise of the right of reply in the first instance, then it is mandatory for the state to provide legal remedy against the first court decision). ${ }^{3}$

1 Media Libel Law 2011-12. Reports from all Fifty States, the Federal Courts of Appeals, U.S. Territories, Canada and England. Edited by the Media Law Resource Center, Inc. Oxford University Press, 2011; Fleming, J.: Retraction and Reply: Alternative Remedies for Defamation. University of British Columbia Law Review, 12 (1978) 1, 15.

2 Directive 89/552/EC of the European Parliament and of the Council on the coordination of certain provisions laid down by law, regulation or administrative action in Member States concerning the pursuit of television broadcasting activities (hereinafter: the Television Without Frontiers Directive) and, since 2010, Directive 2010/13/EU on the coordination of certain provisions laid down by law, regulation or administrative action in Member States concerning the provision of audiovisual media services (Audiovisual Media Services Directive, the AVMS Directive).

3 Castendyk, O.-Dommering, E.-Scheuer, A. (eds): European Media Law. The Hague-LondonBoston, 2008. 733-758. 
Without putting the burden of legal regulation on them, the European Parliament and the Council recommended to the Member States the establishment of the right of reply with a significantly broader scope than the Directive and supported its introduction in respect of online content provision as well as television services. ${ }^{4}$

\section{Documents of the Council of Europe}

The first document of the Council of Europe concerning the subject was a 1974 decision, one of the first documents concerning the freedom of the press prepared within the framework of the legal development and standard-setting activities of the international organisation. The decision states that the freedom of the press involves obligations and responsibilities, too, and that the interest of the community is to access information from diverse sources. Accordingly, the member states are required to ensure the right of reply of injured individuals against injurious statements of facts and opinions. As such, while the right belongs to the injured individual, it also serves the community striving to access information. ${ }^{5}$

The 2004 recommendation of the Council of Ministers expressed that it would be desirable to extend the right of reply over the online environment as well. The recommendation also stresses that access to information from a variety of sources is in the interest of the community but, in comparison with the previous decision, it limits the desirable object of the right of reply and only requires its implementation in the various legal systems in respect of false or inaccurate statements of fact. ${ }^{6}$

The European Convention on Transfrontier Television provides for the right of reply in a manner similar to that of the EU Directive. ${ }^{7}$

\section{The case law of the European Court of Human Rights}

In the case Ediciones Tiempo S. A. v. Spain (app. no. 13010/87, decision of 12 July 1989) the European Court of Human Rights rejected the application. The complainant press publisher sought remedy from the Court after having been ordered by the Spanish courts to publish a reply. According to the complainant this involved the publication of information known to be false by the complainant, which violated the complainant's freedom to publish information and the freedom of the press. In its decision, the Court established that the right of reply is an instrument serving the public's right to information; on the basis of the Court's decision its role of protecting the personality of the injured party is secondary to this. The public's right to information from diverse sources and the circumstance that the reply has to be published within a short time from the original publication make it unnecessary and impossible to examine the truth of the content of the reply.

${ }^{4}$ Recommendation of the European Parliament and of the Council of 20 December 2006 on the protection of minors and human dignity and on the right of reply in relation to the competitiveness of the European audiovisual and on-line information services industry (2006/952/EC).

5 Council of Europe Committee of Ministers Resolution (74) 26 on the Right of Reply-Position of the Individual in Relation to the Press (Adopted by the Committee of Ministers on 2 July 1974, at the 233rd meeting of the Ministers' Deputies).

${ }^{6}$ Recommendation Rec(2004)16 of the Committee of Ministers to member states on the right of reply in the new media environment (Adopted by the Committee of Ministers on 15 December 2004 at the 909th meeting of the Ministers' Deputies).

${ }^{7}$ European Convention on Transfrontier Television, Strasbourg, 5. V. 1989., art. 8. 
In the case Melnychuk v. Ukraine (app. no. 28743/03, decision of 5 July 2005) the European Court of Human Rights went even further and established that the right of reply is part of the freedom of speech of the complainant. That is, rather than limiting the freedom of the press of the publisher of the paper carrying the injurious content, the opposite is true: the right is an instrument that enables the complainant to effectively exercise the freedom of speech in the forum where the complainant has been attacked. The task of the state is to ensure this possibility. Nevertheless, the Court ruled that the complaint could not be accepted because the content of the statement the complainant wished to have published went beyond the admissible limit, i.e. the content of the original publication. (The Court used the same argumentation in the case Vitrenko and others v. Ukraine [app. no. 23510/02, decision of 16 December 2008].)

The case Kaperzynski v. Poland [app. no. 43206/07., decision of 3 April 2012] concerned a journalist's criminal conviction for failing to publish a reply to a defaming article. The journalist was sentenced to 20 hours community service per month (for 4 months, but suspended) and deprived him of the right to work as a journalist for 2 years. The Strasbourg Court found that the applied sanctions were disproportionate, and therefore had not been necessary in a democratic society, so the state violated the applicant's right to free speech. The Court argued that a criminal measure as a response to defamation cannot, as such, be considered disproportionate, but also considered that the relevant sections of the Polish Press Act had subsequently been found unconstitutional by the Polish Constitutional Court.

As regards the right of reply, the Court reinforced its earlier rulings: "The Court is of the view that a legal obligation to publish a rectification or a reply may be seen as a normal element of the legal framework governing the exercise of the freedom of expression by the print media. It cannot, as such, be regarded as excessive or unreasonable. Indeed, the Court has already held that the right of reply, as an important element of freedom of expression, falls within the scope of Article 10 of the Convention. This flows from the need not only to be able to contest untruthful information, but also to ensure a plurality of opinions, especially on matters of general interest such as literary and political debate..." (para. 66). ${ }^{8}$

\section{Comparative overview of certain issues related to the right of reply ${ }^{9}$}

\section{The nature of the source of law governing the institution}

Although it has no direct bearing on the content and limitations of the right, it is nevertheless important to know which and what type of source of the law governs the right of reply in the various states. In those states where the issue is managed via the instruments of state regulation, the institution is usually provided for by law (most often the special sectoral law dealing with the media), although in several countries this right has gained constitutional

${ }^{8}$ For the overview of relevant ECHR case law, see: Björgvinsson, D. T.: The Right of Reply. In: Casadevall, J.-Myjer, E.-O'Boyle, M.-Austin, A. (eds): Freedom of Expression. Essays in Honour of Nicolas Bratza. Oisterwijk (the Netherlands), 2012. 170-174.

${ }^{9}$ During the overview of the various national regulations we have relied, to a great extent, on the findings of the international study conducted by DLA Piper Hungary on behalf of the National Media and Infocommunications Authority in 2011-12. The study was conducted on the basis of the legal provisions effective on 31st March 2012. The author received information after that date concerning the development of the regulation in Poland, and is grateful to Beata Klimkiewicz for that. 
rank. The significance of this is immense, since in these countries the right of reply has become a constitutional (fundamental) right is on a par with the fundamental right of the freedom of the press. In these instances, therefore, it is obvious that in principle the right of reply entails an admissible limitation of the freedom of the press.

At the same time, this inference is also possible via legal interpretation rather than constitutional codification. This is what the European Court of Human Rights did when it established that the right of reply is an essential element of the freedom of speech and the freedom of the press of the party intending to publish the reply and therefore, if disputes arise in the context of this right, the point of reference for both sides will be the exercise of press freedom and the freedom of speech (it being the freedom of the media on the one side and the freedom of the person initiating the publication of the reply on the other).

From the member states of the European Union, one can find the right of reply in the constitutions of Greece, Portugal and Slovenia.

According to article 14 par. 5 of the Greek Constitution, "Every person offended by an inaccurate publication or broadcast has the right to reply, and the information medium has a corresponding obligation for full and immediate redress. Every person offended by an insulting or defamatory publication or broadcast has also the right to reply, and the information medium has a corresponding obligation to immediately publish or transmit the reply. The manner in which the right to reply is exercised and in which full and immediate redress is assured or publication and transmission of the reply is made, shall be specified by law."

The right of reply and rectification is a fundamental right set forth in article 37 no 4 of the Portuguese Constitution. Pursuant the referred article, "Every natural and legal person shall be equally and effectively ensured the right of reply and to make corrections, as well as the right to compensation for damages suffered..." (The right of reply and the right to indemnification are related to the freedom of opinion and the freedom of the press discussed in the first three paragraphs of art. 37.)

Article 40 of the Slovenian constitution declares that "The right to correct published information which has damaged a right or interest of an individual, organization or body shall be guaranteed, as shall be the right to reply to such published information."

All three constitutional provisions make a distinction between and mention separately the (broader) right of reply and the (narrower) right of correction. The fact that both the Greek and the Portuguese legal systems regulate the right of reply in the broad sense and provide for the publication of reply statements in the case of the publication of injurious opinions, too, is related to this characteristic. On the other hand, the Slovenian media regulations provide for the right of reply only in the event of the publication of false statements of fact, even though the constitution names the right of correction and the right of reply separately.

From those European countries that are not members of the Union, Croatia, ${ }^{10}$ Macedonia, ${ }^{11}$ Turkey $^{12}$ and the Ukraine ${ }^{13}$ have elevated the right of reply to the rank of fundamental right. The significance of this is mainly symbolic, since the actual assertion of the right does not have a clear and close connection with the nature of the source of law

10 Constitution of Croatia, art. 38 (4).

11 Constitution of Macedonia, art. 16.

12 Constitution of Turkey, pt. 2, ch. 2, § XI, art. 32.

13 Constitution of Ukraine, art. 32. 
governing it and its position within the hierarchy of the sources of the law. The constitutional nature of the right does not entail that it may limit the freedom of the press and vice versa: the limitation of the latter may be admissible even if the right of reply is not part of the constitution.

There are European States where the right of reply is provided for by the general civil code. Such, for example, is the Dutch right of reply, which is the right of correction or rectification in the narrow sense. ${ }^{14}$ (Between 1977 and 2010, the Hungarian regulation applied a similar solution, too.)

Within the European Union there are very few states where the law provides for no right of reply or right of rectification. One such is the United Kingdom, the other is Sweden. In the case of the latter, however, the contract between the media service providers authorised to use frequencies and the media authority may prescribe the obligation to publish replies, which can therefore become a legal obligation without any act of law. ${ }^{15}$ In practice all media services using state-owned frequencies are obliged by contract to publish replies. In Sweden the actors of the media market settle the issue of the right of reply between themselves within the framework of self-regulation. ${ }^{16}$ Bulgaria applies a unique solution: while the media service regulations do provide for the right of reply, in the case of press products it is subject only to self-regulation. ${ }^{17}$

Another solution used is that the general provisions of legal acts are expounded in a code-typically prepared by the media authority-which defines the detailed rules. For example, this solution is applied by the Romanian media regulations. ${ }^{18}$

The prescription of the right of reply (either uniformly, in a single legal act for all media or in several legal acts in a differentiated manner for the various types of media) is common to the media regulations of EU member states.

\section{The material scope of the regulation}

Two questions arise in respect of the material scope of the regulation of the right of reply by the state. The first is whether the regulations differentiate between the various types of media, i.e. whether they contain different provisions for media services or press products or perhaps exempt one of these from the scope of the regulations. The other one is whether, during recent years, the regulations have changed and been extended over new media content services including, especially, online (textual) content services and on-demand media services.

The review of the regulations of the various EU member states shows that most of them provide for the right of reply in a uniform manner, i.e. the same norm applies to media

14 Dutch Civil Code, art. 6-167.

15 Radio and Television Act (Sw. Radio-och tv-lag (2010:696), Ch. 4 s. 9 para. 11.

16 Code of Ethics for Press, Radio and Television, s. 5 and 13.

17 Independent Study on Indicators for Media Pluralism in the Member States-Towards a RiskBased Approach. Prepared for the European Commission Directorate-General Information Society and Media by K.U. Leuven-ICRI, Jönköping International Business School, MMTC Central European University, CMCS Ernst and Young Consultancy Belgium. Leuven, July 2009. (Hereinafter: Independent Study on Indicators for Media Pluralism). Country Reports-Bulgaria.

18 Decision no. 187 of April 3, 2006 Concerning the Regulations of the Content of Audiovisual Programme Services, art. 48. 
services and press products, although it is also true that online services fall under the scope of the regulations in only a minority of these states.

At the same time, Belgium, ${ }^{19}$ France, ${ }^{20}$ Latvia $^{21}$ Italy ${ }^{22}$ and Slovakia apply differentiated regulations, i.e. in these states separate acts of law provide for the rules applicable to the media and to the press, even if there are no significant differences between the content of these.

The Slovakian regulations provide for a much broader right of reply in the case of press products (where the publication of the actual reply statement may be demanded) than for media services (where only rectification may be demanded). ${ }^{23}$ On the other hand, the Finnish regulations differentiate on the basis of the personal status of the applicant rather than the type of the service: if the offended party is a private individual they are granted the right of reply, while legal persons or authorities are only granted the right to publish rectification. ${ }^{24}$

In Ireland an act provides for the right of reply in respect of media services. ${ }^{25}$ At the same time, a "hybrid" solution is applied with regard to press products. The Defamation Act of 2009 created the legal basis for the existence of the industry's already established self-regulatory body, the Press Council. The act entrusts this organisation with drawing up the rules (the Code of Conduct) applicable to the press. Accordingly, the obligation of the publication of reply statements is provided by this Code of Conduct formulated by the Press Council.

"Principle 1. Truth and accuracy

1.2. When a significant inaccuracy, misleading statement or distorted report or picture has been published, it shall be corrected promptly and with due prominence."

"1.3. When appropriate, a retraction, apology, clarification, explanation or response shall be published promptly and with due prominence."

On the basis of the Code of Conduct the Press Ombudsman is entitled to proceed and investigate complaints. It is mandatory for the press product to publish the condemnatory decision if so ordered by the Press Ombudsman. ${ }^{26}$

The Bulgarian regulation is similar, too. There, an act provides for the right of reply in respect of media services, while a self-regulatory code applies to the press; this provides for

19 Valcke, P.-Lievens, E.: Media Law in Belgium. Alphen a/d Rijn, 2011. 67-68, 105. See Federal Act of 23 June 1961 (Loi relative au droit de réponse; on the right of reply in the press); concerning the audiovisual media, see the Decree of 27 March 2009 in the Flemish Community, the Decree of 27 June 2005 in the German Community, the Act of 23 June 1961 in the French Community.

201881 Press Act and Law of 29 July, 1982.

211995 Act on Radio and Television, art. 36-37, 1990 Law on the Press and other Mass Media, art. 21 .

${ }^{22}$ Legislative Decree 31 July 2005, no. 177 (Media Code), Section 8 of the Law 8 February 1948, no. 47 (Printed Press Law).

23 Press Law no. 167/2008, art. 8; Act on Broadcasting and Retransmission, art. 21; Skolkay, A.: Media Law in Slovakia. Alphen a/d Rijn, 2011. 89, 139-140.

${ }^{24}$ Act on the Exercise of Freedom of Expression in Mass Media, Ch. 3, s. 8-9.

25 Broadcasting Act 2009 s. 49.

26 Defamation Act 2009, Schedule 2. 9; Carolan, E.-O’Neill, A.: Media Law in Ireland. DublinHaywards Heath, 2010. 495-512. 
the right of reply as well, but only in respect of those actors who accept the code as mandatory. 27

Several member states of the European Union have extended the scope of the right of reply over online press products; such states are Austria. ${ }^{28}$ Denmark, ${ }^{29}$ Estonia, ${ }^{30}$ Finland, ${ }^{31}$ France, ${ }^{32}$ Germany, ${ }^{33}$ Hungary, ${ }^{34}$ Luxembourg, ${ }^{35}$ Poland, ${ }^{36}$ Portugal $^{37}$ and Slovenia. ${ }^{38}$ In some of these states this is expressly provided for by law (either specifically nominating online press products or by applying a definition of the "press" that is general enough to include contents disseminated via any technology), while in others the interpretation and development of the law by the courts has extended the scope of the regulations to the new services.

27 Independent Study on Indicators for Media Pluralism op. cit. (n. 16.), Country Reports Bulgaria.

28 In general terms, regulations of the Media Act (Mediengesetz, Federal Act on the Press and other Publication Media 12 June 1981, Federal Law Gazette No. 314/1981) addressing printed press do also apply to online newspapers and other internet portals (with the exceptions to websites containing information that do not go beyond the presentation of the personal sphere of life or the pure presentation of the media owner). According to Art. 1, s. 1. 1. § 5.a. "periodical electronic media" means "a media which is electronically a) broadcast (broadcast programme) or b) to be downloaded (website) or c) disseminated in comparable makeup at least four times each year (recurrent electronic media)."

${ }^{29}$ Danish online newspapers/periodicals fall under the scope of the Media Liability Act no. 85 of 9 February 1998.

30 The Code of Ethics for the Press is applicable to electronic newspapers as well. See Independent Study on Indicators for Media Pluralism op. cit. (n. 17.), Country Reports-Estonia.

${ }^{31}$ In Finland the term "network publication" includes the online newspapers and news portals as well ("Network publication means a set of network messages, arranged into a coherent whole comparable to a periodical from material produced or processed by the publisher, and intended to be issued regularly", see Act on the Exercise of Freedom of Expression in Mass Media, s. 2.1.6.).

32 French courts widely admit that the Press Act also applies to online communication.

33 The electronic press is covered by the German laws as "telemedia with journalistic editorial content", which is regulated by the RStV (Interstate Treaty on Broadcasting). According to art. 54 of the RStV Telemedia with journalistic editorial content, where in particular content of periodical printed publications in text or pictures is displayed in full or in part, has to observe the accepted journalistic principles.

34 Act no. 104 of 2010 (Press Freedom Act) $\S 1$.

35 Act of 8 June 2004 on the Freedom of Expression in Media (Loi du 8 juin 2004 sur la liberté d'expression dans les medias) equally applies to internet press. Media is defined as any technical means, material or immaterial, used for publication. Publication means information made available to the public or a category of the public by an editor by means of media.

36 Online newspapers or news portals are subject to the general provisions laid down in the Press Act if they fall within the definition of "press" set out in the Press Act of 26 June 1984.

37 Although there is no express rule which establishes the application of the Printed Press Law (Law no. 2/99 of 13 January as amended by Law no. 18/2003 of 11 July) to internet press, the rules regarding printed press may also apply to online newspapers and to all internet content which include journalistic material.

38 The provisions of the Media Act (Official gazette of the Republic of Slovenia (Uradni list RS No. 35/2001) generally do not exclusively refer to specific kinds of media, so it applies to publications on the internet as well. 


\section{Is the application of the right of reply limited to statements of facts or does it extend over statements of opinion, too?}

As we have seen, the regulations of the European Union and the recommendations of the EU and the Council of Europe find it sufficient if the various legal systems provide for the right of reply in respect of false statements of fact. Therefore, several member states of the European Union only provide for the right of reply against such statements. At the same time, in certain member states the regulation is applicable in respect of injurious statements of opinion, too. The Finnish legal system admits the right of reply in the case of "offensive" opinions. $^{39}$

Under Luxembourgian law anyone who is recognisable or identifiable on the basis of the original media content may demand the publication of a reply statement, irrespective of whether the information or opinion published about that person was injurious or not.

"Without prejudice to his other rights, each natural or legal person, each association or entity referred to by name or implicitly in a periodical publication has the right to request a right of reply free of charge" 40

French law admits the right of reply with a similarly broad scope in respect of press products, while in the case of media services it allows the exercise of this right if the statement of opinion jeopardises honour. ${ }^{41}$ Under Maltese, Portuguese ${ }^{42}$ and Greek ${ }^{43}$ law, reply statements may also be published against statements of opinion; in the case of Greece this is provided for by the constitution.

Until 2012, Polish law admitted the right of reply in all media in respect of content threatening personality rights. ${ }^{44}$ Due to the resolution of the Polish Constitutional Tribunal (Resolution of the Constitutional Tribunal, 1 December 2010, case file: K 41/07), Article 31 of the Press Act was amended. The Constitutional Tribunal ruled that Article 31 in its previous form, is not in harmony with the Polish Constitution, as it did not precisely distinguished between "corrections" and "responses". According to the Constitutional Court, the lack of specification what a correction should be, or how a letter of complaint should be published, has affected the editors' decisions on this matter, and was considered as an intrusion into media freedom. According to the amended Article 31, now "correction" is the only form of the right of reply. It serves to correct incorrect information and facts published by the media.

Maltese law incorporates the right of reply against the media with an extremely broad scope. The Press Act (Chapter 248 of the Laws of Malta), which covers broadcasting as

39 Act on the Exercise of Freedom of Expression in Mass Media, Ch. 3, s. 8.

40 Act of 8 June 2004 on the Freedom of Expression in Media (Loi du 8 juin 2004 sur la liberté d'expression dans les médias), art. 36.

411881 Press Act, art. 13. and Law of 29 July 1982, art. 6.

42 Portuguese Constitution, art. 34(4), Press Law (Law no. 2/99 of 13 January as amended by Law no. 18/2003 of 11 July) art. 24.

43 Constitution of Greece, art. 14, Law $100 / 2000$ on private audio and audiovisual media, art. 9, Law 1730/1987 on public radio and television, art. 3 paras 12-14, Law 1092/1938 on print media, art. 37-38. See more in Independent Study on Indicators for Media Pluralism op. cit. (n. 17.), Country Reports-Greece.

44 Press Act of 26 June 1984, art. 31. 
well, deals with the right of reply in Article 21. It refers to persons "whose actions or intentions have been misrepresented or who have been subjected to an attack on their honour, dignity or reputation, or to an intrusion into their private life by means of or in a newspaper or in any broadcast..."

In these states the right of reply in respect of statements of opinion is generally admitted in the case of both media services and press products.

As opposed to this, in Latvia ${ }^{45}$ and Bulgaria ${ }^{46}$ such a right only exists in respect of media services, while in Sweden it may only be instituted on the basis of the contract between the linear media service providers and the media authority. ${ }^{47}$ In Belgium and Italy the publication of replies to statements of opinion may only be demanded from press products; in the former anyone who is recognisable or identifiable from an article may demand this (irrespective of whether the opinion published is injurious or not), ${ }^{48}$ while in the latter country the publication of a reply may be demanded by persons whose honour and dignity is jeopardised by the given statement of opinion. ${ }^{49}$ In Ireland, a special solution is applied: the press ombudsman may oblige the publishers of press products to publish replies to injurious opinions. ${ }^{50}$

Without exception, all states that recognise the institution of the right of reply permit its exercise in the event of false statements of fact being published. At the same time, the regulations of the various states differ in whether the scope of the right extends over false statements of fact that result in no injury (of personality rights), i.e. whether any (not necessarily injurious) false statement of fact may form the basis for the exercise of the right of reply or whether it is limited to false statements of fact that are infringing personality rights (defamatory or jeopardising honour).

The latter solution is used more often, nevertheless the legal systems of Luxembourg ${ }^{51}$ and the Hungary ${ }^{52}$ opted to apply the former, i.e. in these states any false facts concerning the applicant form the basis of the exercise of the right of reply with regard to both media services and press products. France, ${ }^{53}$ Italy $^{54}$ and Belgium ${ }^{55}$ opted for this regulatory solution, too, albeit only for press products.

Furthermore, it is an important procedural law issue whether the exercise of the right of reply requires the demonstration of the falsehood of the original statement and the veracity of the content of the reply during the course of the procedure. Under Austrian ${ }^{56}$ law, the reply may only be published if its veracity is demonstrable. According to the

45 Radio and Television Act (1995) art. 37. See Independent Study on Indicators for Media Pluralism op. cit. (n. 17.), Country Reports-Latvia.

46 Law on Radio and Television, Prom. SG. 138/24 Nov 1998, art. 18.

47 Radio and Television Act (Sw. Radio- och tv-lag (2010:696), Ch. 4 s. 9 para. 11.

48 Federal Act of 23 June 1961 (Loi relative au droit de réponse), art. 1.

49 S. 8 of the Law 8 February 1948, no. 47 (Printed Press Law).

50 Defamation Act 2009. Schedule 2. 9; Carolan-O'Neill: op. cit. (n. 26).

51 Act of 8 June 2004 on the Freedom of Expression in Media (Loi du 8 juin 2004 sur la liberté d'expression dans les médias), art. 36.

52 Act 104 of 2010 (Press Freedom Act) § 12.

531881 Press Act, art. 12-13.

54 S. 8 of the Law 8 February 1948, no. 47 (Printed Press Law).

55 Federal Act of 23 June 1961 (Loi relative au droit de réponse), art. 1.

56 Mediengesetz, Federal Act on the Press and other Publication Media 12 June 1981, art. 1. s. 1. $§ 9(1)-(2)$. 
relevant Hungarian procedural rule, the veracity of the statements of the applicant is to be assumed; however, if the publisher of the injurious statement is able to refute the veracity of the contents of the reply statement "immediately" (at the beginning of the procedure, by the first trial date), then the publisher is relieved from the publication duty. ${ }^{57}$ The provisions of the Danish ${ }^{58}$ and Latvian ${ }^{59}$ laws are similar, too.

According to the special solution of Portuguese law, if, after publication, it is found that a fact stated in the reply or correction published in the press product was false, then the author of the reply is required to pay the price of the "space" used by the reply (as if the author had purchased advertising space). This rule also applies if the length of the reply statement exceeds the maximum provided for by law (300 words or the length of the original statement if that was in excess of 300 words); in such a case the press is required to publish the reply in its entirety, but the publication of the excess content must be paid for by the party exercising the right of reply. ${ }^{60}$ Another rule specific to Portugal which creates a special kind of right of reply is that the opposition parties of parliament may refute the political position statements of the government published in public service media that have direct bearing on the opposition parties. ${ }^{61}$

\section{The cases of relief from liability}

Relief from the duty of the publication of the reply statement is only possible if one or more of the causes defined by the regulation exist. It is a fundamental principle that the reply statement must conform to certain criteria. Typically, these concern the language and maximum length of the reply. It is also important that the reply statement itself may not be in breach of the law (e.g. slanderous or defamatory) and that its content must pertain to the content of the original statement. The Cypriot ${ }^{62}$ and the Luxembourg ${ }^{63}$ regulations provide that the content of the reply may not offend "public morals" (in the case of the former, this provision only applies to linear media services). Besides this, strict procedural rules apply to the manner of the vindication of the right, e.g. in respect of the time limit of handover.

If, however, the applicant observes the content and procedural requirements of the statement, the obligor typically may not deny the publication of the reply. That is, in most countries the obligor's responsibility is objective without the possibility of freeing them from blame. There are a few exceptions to this that allow relief from liability within a limited scope.

57 Paragraph (2) of Article 342 of Act III of 1952, On the Code of Civil Procedure.

58 Media Liability Act no. 85 of 9 February 1998, s. 36. ("Requests for reply in the mass media to information of a factual nature which might cause anyone significant financial or other damage, and which has been published in a mass media, must be heeded, except where the correctness of the information is unquestionable."). See Sandfeld Jakobsen, S.-Schaumburg-Müller, S.: Media Law in Denmark. Alphen a/d Rijn, 2011. 91-92.

59 Radio and Television Act (1995), § 36 (3); Szalai, A.-Szőke, G. L.: A média szabályozása Észtországban, Lettországban és Litvániában (The regulation of the media in Estonia, Latvia and Lithuania). Budapest, 2010. 39.

${ }^{60}$ Press Law (Law no. 2/99 of 13 January as amended by Law no. 18/2003 of 11 July), art. 25-26.

${ }^{61}$ Law no 27/2007 of July 30 (Television and On-Demand Audiovisual Services Law), art. 64 (1) and the Law no 54/2010 of December 24 (Radio Law), art. 57 (1).

62 Radio and Television Stations Law of 1998, art. 44.

63 Act of 8 June 2004 on the Freedom of Expression in Media (Loi du 8 juin 2004 sur la liberté d'expression dans les médias), art. 41 para. a). 
In certain states, relief from liability is possible in respect of the publication of statements and opinions (dissemination) originating from third parties. According to the justification of this reason for freeing the publisher from blame, alleged information does not originate from the medium publishing it, and, since it is the duty of the medium to present the various relevant positions, it cannot be held liable for performing this duty. This concept, however, is only professed by the legal system of a few states, since none of the arguments in favour of the existence of the right of reply would be affected by the fact that the statement forming the basis of the reply did not originate from the medium or journalist publishing it: this has no bearing on the injury of personality rights and the publication of the reply serves the information of the public in this case, too.

In the Czech Republic, a radio and television broadcaster shall not be obliged to transmit a reply if "the challenged communication or part thereof is quoted from a third party's communication intended for the public, or is a true interpretation thereof, and was marked or presented as such." ${ }^{\prime 64}$

In Malta, the right of reply in the press shall not apply to any privileged publications (in cases where no action lies under that article in respect of such publication).

Under Article 33 of the Press Act (Chapter 248 of the Laws of Malta), the following are the "privileged publications":

“(a) publications made in pursuance of an Act of Parliament or by authority of the President of Malta or of the House of Representatives;

(b) publications consisting of communications between public officers, or between such officers and contractors of the public service or officials of public corporations, reports of inquiries held in terms of any law, or statements by public officers that are made in good faith in the interests of national security, territorial integrity, public safety, for the prevention of disorder or crime or for the protection of health or morals; (c) publications of bona fide reports of debates of the House of Representatives, provided the relevant part of the debate is published, and the defence of any person against whom any charge is made is not suppressed or maliciously or negligently curtailed or altered;

(d) publications of reports of any proceedings in a court of justice in Malta, provided such reports are fair reports of the proceedings and the publication of such reports or proceedings is not prohibited by law or by the court:

Provided that it shall not be lawful to publish (a) anything which, by article 994 of the Code of Organization and Civil Procedure, is forbidden to be used or produced, or (b) any report of the proceedings in any case of defamation, in which evidence of the truth of the matters charged is not allowed by law."

In Slovakia, under the press law, a public official, a chairman of a political party or political movement, a vice-chairman of a political party or political movement or a legal entity represented by these persons does not have the right of reply in relation to a statement of fact concerning the exercise of their function. ${ }^{65}$

64 Act no. 231/2001 Coll. [Radio and Television Broadcasting Act art. 40 c)], Act. no 46/2000 Coll. (Press Act) s. 10-15.

65 Act No. 167/2008 Coll. on Periodicals and Agency News Service, $\S 8$ (2). Markechova, J.: Slovakia-Amendment to the Press Act. IRIS 2011-8:1/43 http://merlin.obs.coe.int/iris/2011/8/ article43.en.html. 
According to the Act, the publisher of a periodical and a press agency shall not be responsible for "the content of information provided by a public authority, a budgetary organisation or grant-funded organisation established by them or a legal entity established by law, if this information is published in the periodical or agency news service in its original form and its processing for publication has not changed its original content..."66

In Austria, there is no obligation to publish a counterstatement or subsequent information if it refers to a true report on a hearing in a public session of the National Council, the Federal Council, the Federal Assembly, a State Parliament or any committee of the above general bodies of representation.

In other cases, the obligation does not exist if the person concerned has been offered adequate opportunity to comment in the same or a different but equivalent release and has not made use of it or if, before receipt of the counter-statement, an equivalent editorial correction or supplement has been published. ${ }^{67}$

According to the Audiovisual Code of Romania, ${ }^{68}$ a right of reply cannot be requested when licence holders did abide by the principle of "audiatur et altera pars," when he/she did receive an opportunity to respond to any criticism against him/her.

In Iceland, media service providers may reject a request to reply "if the information broadcast by the media service provider consists of direct citations of content originating from government authorities or courts of law." 69

The case law of Hungarian courts has shifted to a more lenient approach toward dissemination (exemption from liability of persons disseminating information), even without any statutory changes. On the basis of Supreme Court Decision EBH2001. 407, members of the press reporting on proceedings falling within the competence of the Parliament, local governments, various national and local public administration bodies and the organs of the judiciary "are not required to have evidence for the truthfulness of their statements", and, consequently to publish reply statements. Similarly, the press may not be required "to verify the statements made at a press conference by a police officer" (BH2002. 51.), and to publish corrective statements. Similarly, "press correction may not be sought if the press publishes correct information about a fact established in a criminal, civil, or public administrative action before the completion of the proceedings" (BH2004. 273.), even if the information subsequently turns out to be false in the course of the proceedings.

\section{$V$. The sanctions applicable in the event of infringement of the right of reply}

Upon the conclusion of the proceedings of a court or in some states the media authority directed at the publication of a reply statement, the obligation of the publication thereof is a possible legal sanction in all cases. Under Hungarian law, for example, the obligation to publish is the only possible sanction that is applicable upon the conclusion of the procedure. ${ }^{70}$ Under several legal systems, however, the application of a fine is also possible if it is proved that the given medium unreasonably denied the publication of the reply.

66 Act No. 167/2008 Coll. on Periodicals and Agency News Service, § 5 (2).

${ }^{67}$ Media Act (Mediengesetz), Federal Act on the Press and other Publication Media 12 June 1981, Federal Law Gazette No. 314 (1981) § 11.

${ }^{68}$ Decision no. 187 of 3 April 2006 Concerning the Regulations of the Content of Audiovisual Programme Services, art. 48.

69 Media Law No. 38. of 20 April 2011, Art. 36.

70 Act 104 of 2010 (Press Freedom Act) $§ 12$. 
The nature of the fine sanction also varies among the different states, according to whether it may be imposed by a court or an authority and whether it is imposed as a public administrative or criminal law sanction. In certain states the regulations are differentiated in this respect, too: in Cyprus, for example, in respect of linear media services it is the media authority that may impose fines while in the case of press products this may be done by the courts. ${ }^{71}$ Sanctions are also imposed by courts in Belgium, ${ }^{72}$ Finland, ${ }^{73}$ Denmark, ${ }^{74}$ France and Poland, generally, i.e. in respect of all media. In France the failure to publish the reply statement may also result in up to three months' imprisonment. ${ }^{75}$ The maximum term of imprisonment is four months in Denmark. ${ }^{76}$ In Poland, besides fines, imprisonment is also an admissible punitive measure. ${ }^{77}$ In Portugal both the courts and the authorities may proceed in cases related to the infringement of the right of reply and may apply potentially severe fines (a maximum of $€ 15,000$ for the press and $€ 375,000$ for media services). ${ }^{78}$ In Italy the media authority is entitled to proceed in cases related to the right of reply in respect of both linear media services and press products and may impose fines. ${ }^{79}$

A special type of sanction is the order to publish the condemnatory judgement or decision. In Ireland, this may be done by the media authority in respect of linear media services and by the press ombudsman in respect of press products. ${ }^{80}$

\section{Legal instruments similar to the right of reply}

Danish law provides for a special provision that may be considered as an indirect form of the right of reply: Section 273 of the Criminal Code provides that the courts may award a lump sum to victims of slanderous statements. The winning party may use the amount awarded to publish the judgement, i.e. may purchase advertising space or time for the presentation of the judgement (since the medium committing slander cannot be obliged to publish the reply statement via the criminal proceedings, as such obligation may only be imposed on the basis of media regulations). ${ }^{81}$

71 Radio and Television Stations Law of 1998, Printed Press Law (Law 145/89).

72 Federal Act of 23 June 1961 (Loi relative au droit de réponse), art. 6.

73 Act on the Exercise of Freedom of Expression in Mass Media, Ch. 3, s. 11.

74 Pursuant to the Media Liability Act no. 85 of 9 February 1998, s. 49 the Press Council can order the editor of a mass media to publish a verdict from the council without changes.

751881 Press Act, art. 13.

${ }^{76}$ If the editor fails to publish the verdict of the court in a right of reply procedure, he/she is sanctioned with fines and in rare occasions even prison sentence up to 4 months.

77 Press Act of 26 June 1984, art. 46. According to the resolution of the Polish Constitutional Tribunal, art. 46 para. 2 was repealed in 2012, but in the case of corrections, the unjustified denial still can be punished by imprisonment (under art. 46. para. 1).

78 Press Law (Law no. 2/99 of 13 January as amended by Law no. 18/2003 of 11 July), and Section IV of the Chapter V of the Law no. 54/2010 of 24 December (Radio Law) and by the Section IV of the Chapter VI of the Law no. 27/2007 of 30 of July, rectified by the Declaration of Rectification no. 82/2007 of 21 September and amended by the Law no 8/2011 of 11 April (Television and OnDemand Audiovisual Services Law).

79 Legislative Decree 31 July 2005, no. 177 (Audiovisual Media and Radio Services Code), art. 32-quinquies, paras 3-4; Mastroianni, R.- Arena, A.: Media Law in Italy. Alphen a/d Rijn, 2011. $77-78$.

80 Broadcasting Act 2009, Defamation Act 2009.

81 Sandfeld Jakobsen-Schaumburg-Müller: op. cit. (n. 58.) 91. 
Hungarian law admits the civil law sanction of "public restitution" in the event of infringement of personality rights. ${ }^{82}$ The scope of this sanction is broader than that of press correction, since it is applicable to the infringement of any personality right by anyone (in practice the courts apply it in cases of defamation and injury to reputation and against content published in the media). The specific judgements often provide for the obligation of restitution. In such cases, the courts specify the place where such restitution has to be provided (i.e. the press product in which the statement serving restitution has to be published; usually this is the same press product as the one in which the infringement has been committed). The question arises how such judgements can be put to effect, since, unless the court establishes an infringement on the part of the publisher of the press product, the publisher has no obligation to publish the statement of restitution.

Several legal systems differentiate according to the extent of the right of reply and provide for a narrower and a broader right of reply (according to general terminology: the right of reply and the right of rectification/correction) within the same legal act. This solution is applied by French, ${ }^{83}$ Latvian, ${ }^{84}$ Portuguese, ${ }^{85}$ Romanian ${ }^{86}$ and Slovakian ${ }^{87}$ law.

\section{Conclusions}

On the basis of the comparative overview one may formulate some conclusions on the nature and regulation of the right of reply in Europe (or, more precisely, in the member states of the European Union that form the primary subject of the study). Of course, these will not hold true for every single state; however, they do bring to light a specific European model or the European common core ${ }^{88}$ of the right of reply, the major aspects of the regulations and the directions of their development.

A) Although in certain states the right of reply is a constitutional (fundamental) right, it is usually provided for at a lower level of the legal hierarchy. At the same time, the form does not necessarily determine the actual possibility of the exercise of the right, just as the fact of constitutional protection does not determine the hierarchy between the right of reply and the freedom of the press.

B) The legal function of the right of reply is twofold: on the one hand, it serves the protection of the personality rights (the reputation and/or honour) of the person attacked, while, on the other hand, it serves the right of the public audience of the media to appropriate information There is no order of precedence or hierarchy between the two functions; the right of reply serves both. According to the Slovenian media act (Official gazette of the

82 Hungarian Civil Code $84 . \S(1) \mathrm{c})$.

831881 Press Act, art. 12-13.

84 Radio and Television Act (1995) art. 36-37.

85 Press Law (Law no. 2/99 of January 13 as amended by Law no. 18/2003 of July 11), Law no 27/2007 of July 30 (Television and On-Demand Audiovisual Services Law), and the Law no 54/2010 of December 24 (Radio Law).

${ }^{86}$ Law no. 504/July 11th, 2002 (Audiovisual law), art. 41.

87 Press Law no. 167/2008. §§ 7-8.

88 On the concept of common core in comparative law, see: Schlesinger, R. B.: The Common Core of Legal Systems: An Emerging Subject of Comparative Study. In: Nadelmann, K.-von Meheren, A.-Hazard, J.: XXth Century Comparative and Conflicts Law. Legal Essay in Honour of Hessel E. Yntema. Leiden, 1961. 65-79. On the theory of Schlesinger, see: Fekete, B.: A modern jogösszehasonlítás paradigmái (The paradigms of modern comparative law). Budapest. 143-146. 
Republic of Slovenia (Uradni list RS, No. 35/2001) s. 42(1), "The right of reply is intended in the interest of the public in terms of objective, multilateral, and up-to-date information as one of the essential conditions for democratic decision-making in public affairs."

C) The material scope of the right of reply is continuously growing and is gradually starting to cover online media, too. As yet, this is not a general trend, but European-level legislation and the recommended best practices, as well as the practices and regulatory frameworks of the individual states, are developing in this direction. This has both practical and theoretical reasons: the arguments in favour of the institution of the right are the same as in the offline world, and the publication of replies is technically easier on the internet and does not take up any space (transmission time) either. Irrespective of this, in almost all states the approach to the material scope of the right is that it extends over both media services and printed press products.

D) The obligor of the right of reply usually bears objective responsibility in respect of the publication of the reply, i.e. relatively few states provide relief from legal responsibility if, as a precondition to the exercise of the right of reply, the injurious content generating the reply has been published.

E) There are few limitations to the enforcement of the right of reply, i.e. the publication of the reply may solely be denied in exceptional cases. These limitations are typically formal or procedural in nature (language, deadline, length, etc.).

F) The extent of the right of reply exhibits considerable variance in the countries examined according to whether its application is limited to false statements of fact or whether it may be applied in the case of injurious opinions as well. There exists no "general European" solution in respect of this issue, although the majority of states provide for the right of reply only in respect of statements of fact. Approaches vary in respect of statements of fact, too: in certain countries only false and injurious statements may form the basis for the procedure directed at the publication of the reply, while in others false (but not necessarily injurious) statements form sufficient grounds for the procedure.

G) The possible length of the statement of reply (i.e. the maximum length that is mandatory to be published) differs in the various states and conforms to the scope of the right. That is, a broadly interpreted right of reply enables the publication of statements of greater length while, if the right of reply is limited to the right of the correction of false statements of fact, the reply statement is briefer and is limited to a presentation of the false facts and the true state of affairs.

H) The right of reply regularly appears within the systems of self- and co-regulation too; however, it is of great significance whether this is accompanied by state regulation or whether the state relinquishes the supervision of this right in its entirety to an independent organisation. Some form of the right of reply exists in all member states of the EU, which is not independent of the fact that this-partly due to the AVMS Directive-is a member state obligation (although it is also true that such regulations typically originate from times prior to the adoption of the AVMS Directive).

I) Not surprisingly, the results of this comparative study indicate that each EU member state regulates the institution of the right of reply differently. On the basis of the research a model of the right of reply can be outlined that may be regarded as a sort of "common core". This does not mean that all elements of the model are present in all EU member states. However, regulations of a narrower scope than that of these minimum rules exist in few member states (while, at the same time, rules additional to the common minimum are present in several states). The identification of the common minimum is not suitable in 
itself for identifying the best existing solution; the versatility of the regulations and the differences between the individual legal systems would hardly make this possible anyway.

Such a model rule, serving to present the common core, would only be applicable towards statements of fact that are false or injurious to reputation or honour in all "traditional media", i.e. in television and radio media services and printed press products. The media would bear objective responsibility in respect of the publication of the reply statement, i.e. if the applicant did not transgress the legal framework of the exercise of the right, the media could not deny the publication of the reply. The sanction applicable to non-publicationbeside the publication of the statement or the condemnatory decision of the court of law or authority-is the imposition of a fine. Although probably by coincidence only, the Hungarian regulations almost fully conform to these criteria (with the exception that the material scope of the regulations extend over online press products, too, and that no fines or damages are applicable as sanctions in correction cases). 